\title{
1 Salinity alleviates zinc toxicity in the saltmarsh zinc-accumulator Juncus acutus
}

2 Enrique Mateos-Naranjo ${ }^{\mathrm{a}, *}$; Jesús Alberto Pérez-Romero ${ }^{\mathrm{a}}$; Susana Redondo-Gómez

3 Jennifer Mesa-Marín ${ }^{\mathrm{a}}$; Eloy Manuel Castellanos ${ }^{\mathrm{b}}$; Anthony John Davy ${ }^{\mathrm{c}}$

4

5 aDepartamento de Biología Vegetal y Ecología, Facultad de Biología, Universidad de

6 Sevilla, 1095, 41080, Sevilla, Spain

$7 \quad$ bepartamento de Biología Ambiental y Salud Pública, Facultad de Ciencias

8 Experimentales, Universidad de Huelva, 21071, Huelva, Spain

$9{ }^{\mathrm{c}}$ Centre for Ecology, Evolution and Conservation, School of Biological Sciences,

10 University of East Anglia, Norwich Research Park, Norwich NR4 7TJ, UK

11

12

*Corresponding author:

13

Enrique Mateos-Naranjo

14

Dpto. Biología Vegetal y Ecología, Facultad de Biología, Universidad de Sevilla, Av

15 Reina Mercedes s/n, 41012 Sevilla, Spain.

16 E-mail: emana@us.es

17

Tel.: +34-95-4557495; fax: +34-95-4615780 


\section{ABTRACT}

The potential importance of Juncus acutus for remediation of Zn-contaminated lands has been recognized, because of its $\mathrm{Zn}$ tolerance and capacity to accumulate $\mathrm{Zn}$. Since it is also a halophyte, the extent to which salinity influences its $\mathrm{Zn}$ tolerance requires investigation. A factorial greenhouse experiment was designed to assess the effect of $\mathrm{NaCl}$ supply ( 0 and $85 \mathrm{mM} \mathrm{NaCl}$ ) on the growth, photosynthetic physiology and tissue ions concentrations of plants exposed to 0,30 and $100 \mathrm{mM} \mathrm{Zn}$. Our results indicated that $\mathrm{NaCl}$ supplementation alleviated the effects of $\mathrm{Zn}$ toxicity on growth, as $\mathrm{Zn}$ at $100 \mathrm{mM}$ reduced relative growth rate (RGR) by $60 \%$ in the absence of $\mathrm{NaCl}$ but by only $34 \%$ in plants treated also with $\mathrm{NaCl}$. This effect was linked to a reduction in Zn tissue concentrations, as well as to overall protective effects on various stages in the photosynthetic pathway. Thus, at $85 \mathrm{mM} \mathrm{NaCl}$ plants were able to maintain higher net photosynthesis $\left(\mathrm{A}_{\mathrm{N}}\right)$ than in the absence of added $\mathrm{NaCl}$, although there were no differences in stomatal conductance $\left(\mathrm{g}_{\mathrm{s}}\right)$. This contributed to preserving the trade-off between $\mathrm{CO}_{2}$ acquisition and water loss, as indicated by higher intrinsic water use efficiency (iWUE). Hence, $\mathrm{A}_{\mathrm{N}}$ differences were ascribed to limitation in the RuBisCO carboxylation, manifested as higher intercellular $\mathrm{CO}_{2}$ concentration $\left(\mathrm{C}_{\mathrm{i}}\right)$, together with dysfunction of PSII photochemistry (in term of light harvest and energy excess dissipation), as indicated by higher chronic photoinhibition percentages and variations in the photosynthetic pigment profiles in presence of $\mathrm{Zn}$ under non-saline conditions.

Keywords: Chlorophyll fluorescence; Gas exchange; Halophyte; Photoinhibition; Salinity; Zn-stress. 


\section{Introduction}

Juncus acutus L., is a caespitose, halophytic rush, with a sub-cosmopolitan distribution, that inhabits coastal marshes and dune slacks encompassing a wide range of salinity (Fernández-Carvajal, 1982). Together with various other Juncus species, it has been proposed as a bio-tool for wetland restoration projects around the world (Sparks et al., 2013; Marques et al., 2011). In particular, it has potential for the remediation of metal pollution, since it shows great tolerance to excess metals and the capacity to accumulate large amounts of them in its tissues without serious symptoms of toxicity (Mateos-Naranjo et al., 2014; Santos et al., 2014; Christofilopoulos et al., 2016). Medas et al. (2017) have recently suggested that J. acutus is able to optimize its response to metal pollution by tuning different biomineralization mechanisms with the minerals and geochemical conditions of the site. Previous studies of metal accumulation and its effects on the performance $J$. acutus have focused on zinc (Mateos-Naranjo et al., 2014; Santos et al., 2014; Christofilopoulos et al., 2016; Medas et al., 2017), although recently interactions of $\mathrm{Zn}$ with $\mathrm{Cr}$, $\mathrm{Ni}$ and $\mathrm{Cd}$ have also been assessed (Christofilopoulos et al., 2016).

Zinc is an essential element for plant metabolism (Kabata-Pendias and Pendias, 2001). However, its excess can lead to various phytotoxicity effects on plant metabolism (Chaney, 1993), and specifically on halophytic species (Liu et at., 2016). The photosynthetic apparatus (i.e. Calvin cycle and photosystem functionality) is especially sensitive to this ion excess (Van Assche and Clijsters, 1986). Despite such potentially deleterious effects, J. acutus is regarded as Zn-hypertolerant, a feature attributable to a series of physiological and biochemical adaptations. In particular, Mateos-Naranjo et al. (2014) showed that carbon assimilation and the efficiency of PSII were not affected by high concentrations of $\mathrm{Zn}$ in the culture solution. Furthermore, 
Santos et al. (2014) found that maintenance of the functionality of its photosynthetic apparatus was linked with its ability to overcome oxidative damage produced by excess Zn uptake, through the modulation of its antioxidant enzymatic machinery and efficient dissipation of the cellular redox potential consequent on $\mathrm{Zn}$ incorporation into chlorophyll molecules. These studies however, did not take account of the potential interaction of $\mathrm{Zn}$ with other important factors characteristic of marshes ecosystems, particularly salinity. It has been demonstrated that the accumulation of sodium in another halophyte, Spartina densiflora, can mitigate its responses to Zn-induced stress (Redondo-Gómez et al., 2011). Hence knowledge of the extent to which salinity might modulate the physiological responses of $J$. acutus to excess $\mathrm{Zn}$ is necessary for a realistic assessment of its metal toxicity thresholds and its potential for the remediation of zinc-polluted saltmarshes.

This study employed a factorial experiment which aimed to: (1) investigate the influence of $\mathrm{NaCl}$ on the growth responses of $J$. acutus plants exposed to different $\mathrm{Zn}$ concentrations; (2) determine the extent to which this influence could be accounted for by impacts on its photosynthetic apparatus, both in terms of carbon assimilation and efficiency of light-energy use, and (3) assess the nutrient and $\mathrm{Zn}$ accumulation patterns consequent on the joint effects of treatment with elevated $\mathrm{NaCl}$ and $\mathrm{Zn}$.

\section{Material and Methods}

\subsection{Plant material}

Seeds of Juncus acutus were collected in December 2013 from different individuals $(\mathrm{n}=20)$ randomly selected from a well-established population in Doñana National Park (Huelva, SW Spain). The seeds were transported to the laboratory for 
germination in a germination chamber (ASL Aparatos Científicos M- 92004, Madrid, Spain) under the following conditions: photoperiod, $16 / 8 \mathrm{~h}$ light/darkness; temperature, $24 / 15^{\circ} \mathrm{C}$; photon flux rat $(400-700 \mathrm{~nm}), 35 \mu \mathrm{mol} \mathrm{m}^{-2} \mathrm{~s}^{-1}$. Germinated seedlings were immediately transferred to individual plastic pots $(12 \mathrm{~cm}$ in depth, $0.5 \mathrm{~L}$ total volume) filled with perlite and placed in a glasshouse (University of Seville, Greenhouse Service) at controlled temperature of $25 \pm 3{ }^{\circ} \mathrm{C}$, and a relative humidity of $40-60 \%$, with natural day light (maximum quantum flux rate of $1000 \mu \mathrm{mol} \mathrm{m}^{-2} \mathrm{~s}^{-1}$ ). Pots were irrigated with nutrient solution (Hoagland and Arnon, 1938) before the onset of the experimental treatments.

\section{2. $\mathrm{Zn}$ and $\mathrm{NaCl}$ experimental stress treatments}

In June 2014, pots containing the $J$. acutus plants were randomly assigned to three $\mathrm{Zn}$ treatments (concentrations of 0,30 and $100 \mathrm{mM}$ ) in factorial combination with two $\mathrm{NaCl}$ concentrations $(0$ and $85 \mathrm{mM})$ for 40 days. $\mathrm{Zn}$ and $\mathrm{NaCl}$ concentrations were established by combining Hoagland's solution with appropriate amounts of $\mathrm{ZnSO}_{4} \cdot 7 \mathrm{H}_{2} \mathrm{O}$ and $\mathrm{NaCl}$, respectively. Thus, at the beginning of the experiment, the pots were placed in plastic trays containing appropriate solutions to a depth of $1 \mathrm{~cm}(10$ replicate pots per stress treatment combination). In order to avoid changes of $\mathrm{Zn}$ and $\mathrm{NaCl}$ concentration caused by water evaporation from the nutrient solution, levels in the trays were monitored continuously throughout the experimental and topped up to the marked level with Hoagland's solution (without additional $\mathrm{ZnSO}_{4} \cdot 7 \mathrm{H}_{2} \mathrm{O}$ or $\mathrm{NaCl}$ ). Furthermore, $\mathrm{pH}$ of the solution was monitored and adjusted to $6.5-7.0$. The entire solution (including $\mathrm{ZnSO}_{4} \cdot 7 \mathrm{H}_{2} \mathrm{O}$ and $\mathrm{NaCl}$ ) in the trays was renewed weekly and their 
positions were changed randomly every 2 days to avoid effects of environmental heterogeneity inside the glasshouse.

After 40 days of exposure to the stress-inducing treatments, measurements of growth, gas exchange, chlorophyll fluorescence, photosynthetic pigment concentrations and tissue ion concentrations were made.

\subsection{Growth measurements}

Four plants from each treatment were harvested at the beginning of the experiment and a further ten at the end. Plants were divided in roots and shoots and these biomass fractions were oven dried $\left(60^{\circ} \mathrm{C}\right.$ for $\left.48 \mathrm{~h}\right)$ and then weighed. In addition, the number of dead tillers was recorded at the end of the experiment.

The relative growth rate (RGR) of whole plants was calculated using the formula:

$R G R=\left(\ln B_{f}-\ln B_{i}\right) \cdot D^{-1}\left(g^{-1}\right.$ day $\left.^{-1}\right)$

where $B_{f}=$ final dry mass, $B_{i}=$ initial dry mass (the mean of the four plants from each treatment sampled at the beginning of the experiment) and $\mathrm{D}=$ duration of experiment (days).

\subsection{Photosynthetic physiology}



same sections of randomly selected, fully developed photosynthetic tillers $(n=10)$ using an infrared gas analyzer (LI-6400-XT, Li-COR Inc., NE., USA) and a modulated fluorimeter (FMS-2; Hansatech Instruments Ltd., UK), respectively. The following gas exchange parameters were recorded at a light flux density of $1500 \mu \mathrm{mol}$ photons $\mathrm{m}^{-2} \mathrm{~s}^{-}$ 1, ambient $\mathrm{CO}_{2}$ concentration $\left(\mathrm{C}_{\mathrm{a}}\right) 400 \mu \mathrm{mol} \mathrm{mol}{ }^{-1}$ air, leaf temperature of $25^{\circ} \mathrm{C}$ and 50 $\pm 5 \%$ relative humidity: net photosynthetic rate $\left(\mathrm{A}_{\mathrm{N}}\right)$, stomatal conductance $\left(\mathrm{g}_{\mathrm{s}}\right)$, intercellular $\mathrm{CO}_{2}$ concentration $\left(\mathrm{C}_{\mathrm{i}}\right)$, and intrinsic water use efficiency ( $\left.{ }_{\mathrm{i}} \mathrm{WUE}\right)$. The saturation pulse method was used to determine the energy yields of the Photosystem II (PSII) reaction centers: maximum quantum efficiency of PSII photochemistry $\left(\mathrm{F}_{\mathrm{v}} / \mathrm{F}_{\mathrm{m}}\right)$, quantum efficiency of PSII (ФPSII; Genty et al., 1989) and non-photochemical quenching (NPQ). As described by Schreiber et al. (1986), a 0.8 s saturating actinic light pulse of $15000 \mu \mathrm{mol} \mathrm{m} \mathrm{m}^{-2} \mathrm{~s}^{-1}$ was given, at dawn (stable, $50 \mu \mathrm{mol} \mathrm{m} \mathrm{m}^{-2} \mathrm{~s}^{-1}$ ambient light) and midday $\left(1700 \mu \mathrm{mol}\right.$ photons $\left.\mathrm{m}^{-2} \mathrm{~s}^{-1}\right)$, to photosynthetic tillers previously darkadapted or exposed to light for $30 \mathrm{~min}$. $(\mathrm{C} x+c)$ contents of extracts obtained from randomly selected fully developed photosynthetic tillers $(n=5)$, were determined with a Hitachi U-2001 spectrophotometer (Hitachi Ltd., Japan), using three wavelengths (663.2, 646.8 and $470.0 \mathrm{~nm}$ ). For more details, see Mateos-Naranjo et al. (2008). Concentrations of pigments $\left(\mu \mathrm{g} \mathrm{g}^{-1} \mathrm{fw}\right)$ were calculated according to Lichtenthaler (1987).

\subsection{Tissue ion concentrations} $48 \mathrm{~h}$ and ground, according to the protocols of Mateos-Naranjo et al. (2011). Then, 
triplicate $0.5 \mathrm{~g}$ samples from each specific tissue were digested in $6 \mathrm{ml} \mathrm{HNO}, 0.5 \mathrm{ml}$ $\mathrm{HF}$ and $1 \mathrm{ml} \mathrm{H}_{2} \mathrm{O}_{2}$. $\mathrm{Ca}, \mathrm{Mg}, \mathrm{K}, \mathrm{P}, \mathrm{Na}$ and $\mathrm{Zn}$ concentrations in the digests were measured by inductively coupled plasma (ICP) spectroscopy (ARL-Fison 3410, USA).

\subsection{Statistical analysis}

Statistical tests were performed in the software package Statistica v. 6.0 (Statsoft Inc.). Generalized linear models (GLM) were used to analyze the interactive effects of $\mathrm{Zn}$ and $\mathrm{NaCl}$ concentrations (as categorical factors) on the growth and physiological parameters (as dependent variables) of J. acutus plants. Multiple comparisons were analyzed by a LSD (post hoc) test. Before statistical analysis Kolmogorov-Smirnov and Brown-Forsythe tests were used to verify the assumptions of normality and homogeneity of variances, respectively. Differences between tiller and root ion concentrations were compared by the Student test (t-test).

\section{Results}

\subsection{Effects of $\mathrm{Zn}$ and $\mathrm{NaCl}$ on growth}

There were significant effects of both zinc and salinity on the RGR of Juncus acutus but no significant interactions (Table 1, GLM: salinity, $\mathrm{p}<0.05 ; \mathrm{Zn}, \mathrm{p}<0.01$ ). Thus, in non-saline conditions RGR decreased $25 \%$ and $60 \%$ in plants grown at 30 and $100 \mathrm{mM}$ Zn, respectively, compared to control; however, growth was much less affected by $\mathrm{Zn}$ in plants exposed to $85 \mathrm{mM} \mathrm{NaCl}$ (i.e. $11 \%$ and $34 \%$ for 30 and $100 \mathrm{mM}$ Zn, respectively; Fig. 1A). Similarly, the percentage of dead tillers increased sharply with $\mathrm{Zn}$ concentration (GLM: Zn, $\mathrm{p}<0.01)$, but this increase was less acute in plants grown in saline conditions (GLM: salinity, $\mathrm{p}=0.07$; Fig. 1B). 


\subsection{Effects of Zn and $\mathrm{NaCl}$ on photosynthetic physiology}

There were significant effects of salinity and Zn treatments on net photosynthetic rate $\left(A_{N}\right)$ after $40 \mathrm{~d}$ of treatment (Table 1, GLM: salinity, $\mathrm{p}<0.05 ; \mathrm{Zn}, \mathrm{p}<0.01$ and salinity $\mathrm{x} \mathrm{Zn}, \mathrm{p}<0.01)$. Thus $\mathrm{A}_{\mathrm{N}}$ decreased progressively with increasing $\mathrm{Zn}$ concentration in plants grown at both $\mathrm{NaCl}$ concentrations. However, plants exposed to saline conditions maintained higher $\mathrm{CO}_{2}$ assimilation rates at both increased concentrations of $\mathrm{Zn}$ than their non-saline counterparts (Fig. 2A). Very similar trends were recorded for stomatal conductance $\left(g_{s}\right)$ but salinity did not significantly affect the responses to $\mathrm{Zn}$ (GLM: salinity x Zn, $\mathrm{p}=0.06$; Fig. 2B). In contrast, salinity significantly reduced the intercellular $\mathrm{CO}_{2}$ concentration $\left(\mathrm{C}_{\mathrm{i}}\right)(\mathrm{GLM}$ : salinity, $\mathrm{p}<0.05)$, whereas $\mathrm{Zn}$ concentration per se did not. However, $\mathrm{C}_{\mathrm{i}}$ values were reduced at the high salinity only in the presence of excess (30 or $100 \mathrm{mM}$ ) Zn (Fig. 2C). Salinity and Zn had synergistic effects on intrinsic water use efficiency (iWUE; GLM: salinity x Zn, p < 0.05). Thus, plants grown under saline conditions had consistently higher ${ }_{\mathrm{i}} \mathrm{WUE}$ but the difference was only significant at $30 \mathrm{mM}$ Zn (Fig. 2D). and salinity treatments. $F_{v} / F_{m}$ values, both at dawn and midday, tended to decrease with increasing $\mathrm{Zn}$ concentration in plants grown in non-saline conditions. However, in plants exposed to salinity, this effect was less marked and only evident at the highest $\mathrm{Zn}$ concentration treatment (Table $1, \mathrm{GLM}_{\mathrm{Md}}$ and Pd: salinity x Zn, p <0.05; Fig. 3A, B). $\Phi_{\text {PSII }}$ values at dawn and at midday followed a similar pattern to those of $F_{v} / F_{m}\left(G L M_{M d}\right.$ : salinity $x \mathrm{Zn}, \mathrm{p}<0.05$; Fig. 3C,D), except that the differences in predawn values were minimal. NPQ values at midday increased markedly with Zn concentration, both in the absence and presence of salinity, but this effect was substantially stronger in the absence 
of salinity (Table 1, GLM Md: salinity, $\mathrm{p}<0.01$ and Zn, $\mathrm{p}<0.001$; Fig. 3E). Predawn

NPQ did not show any response to Zn or salinity, with values c. 0.15 in all cases (Fig. $3 \mathrm{~F})$.

The percentage of chronic photoinhibition increased progressively with increasing $\mathrm{Zn}$ concentration at both $\mathrm{NaCl}$ concentrations (Fig. 4A,B). However, this increment was more acute in plants grown under non-saline conditions. The percentage of dynamic photoinhition did not vary with salinity or Zn treatments, except in plants grown at the highest $\mathrm{Zn}$ concentration and $85 \mathrm{mM} \mathrm{NaCl}$, which showed a greater percentage inhibition than in the other treatments (Fig. 4A,B).

The concentration of chlorophyll a $(\mathrm{Chl} a)$ was decreased by excess $\mathrm{Zn}$ in the growth medium, although this reduction was entirely mitigated by salinity (Table 1, GLM: salinity x Zn, $\mathrm{p}<0.01$; Fig. 5A). Chlorophyll $\mathrm{b}(\mathrm{Chl} b)$ and carotenoid $(\mathrm{C} x+c)$ concentrations did not show any response to excess $\mathrm{Zn}$ in plants grown in the absence of salinity, but they increased in those exposed to both $\mathrm{Zn}$ and salinity $\left(\mathrm{GLM}_{\mathrm{Chl} b}\right.$ and $\mathrm{C} x+c$ : salinity $x \mathrm{Zn}, \mathrm{p}<0.01$; Fig. 5B,C).

\subsection{Effects of $\mathrm{Zn}$ and $\mathrm{NaCl}$ on tissue ion concentrations}

Tissue ion concentrations were greater in roots than in tillers, except for $\mathrm{K}$ in all specific treatments and for $\mathrm{P}$ in plants grown at $100 \mathrm{mM} \mathrm{Zn}+0 \mathrm{mM} \mathrm{NaCl}, 0 \mathrm{mM} \mathrm{Zn}+$ $85 \mathrm{mM} \mathrm{NaCl}$ and $30 \mathrm{mM} \mathrm{Zn}+85 \mathrm{mM} \mathrm{NaCl}$, (t-test, $\mathrm{p}<0.05$; Table 2). In addition, there were significant effects of salinity and $\mathrm{Zn}$ treatments on tissue ion concentrations except for $\mathrm{K}$ and $\mathrm{Mn}$ tiller concentrations (Table 1). Thus $\mathrm{Zn}$ concentrations increased markedly with the concentration of $\mathrm{Zn}$ in the growth medium in both roots and tillers, but this increment was more acute in the absence of $\mathrm{NaCl}$ addition (GLM: salinity $\mathrm{x} \mathrm{Zn}$, $\mathrm{p}<0.01$; Table 2). Furthermore, tissue $\mathrm{Na}$ concentrations were considerably greater 
under saline conditions and tended to increase with the Zn concentration. Except for roots in presence of $\mathrm{NaCl}$, where $\mathrm{Na}$ concentration showed a reduction with $\mathrm{Zn}$ augmentation (GLM: salinity x Zn, p $<0.01$; Table 2). On the other hand, overall the concentrations of $\mathrm{Mg}, \mathrm{Ca}, \mathrm{P}$ and $\mathrm{Mn}$ in tillers and roots, and $\mathrm{K}$ in roots decreased with the increase of the concentration of $\mathrm{Zn}$ in the growth medium at both saline levels (Table 2). In general, the concentrations of these elements were significantly lower in plants grown with $\mathrm{NaCl}$ supplementation (Table 2).

\section{Discussion}

Understanding the effects of high metal concentrations on tolerant species and the thresholds for phytotoxicity is essential for the design and development of effective methodologies for environmental remediation. Similarly important is knowledge of possible interactions between metals, and between metals and other important environmental factors that may limit species distribution; in estuarine ecosystems interactions with salinity are relevant to the future use of halophytes that can cope with the growing problem of metal pollution of salinized lands (Kholodova et al., 2010).

This experiment confirmed previous work that had demonstrated hypertolerance to $\mathrm{Zn}$ stress in Juncus acutus (Mateos-Naranjo et al., 2014). Thus, the concentration of $\mathrm{Zn}$ required to kill $50 \%$ of its tillers after 40 days of exposure ( $\mathrm{LC}_{50}$; Paschke et al., 2000) was greater than our most severe treatment of $100 \mathrm{mM}$. However, elevated concentrations of $\mathrm{Zn}$ in the culture solution progressively affected plant development, and this was particularly reflected in a clear reduction of RGR and an increase in the percentage of dead tillers. These deleterious effects are consistent with previously described general responses of vascular plants to excess Zn (Vaillant et al., 2005; Mateos-Naranjo et al., 2008; Santos et al., 2014). Nevertheless, we found that Zn 
toxicity was partially counterbalanced by addition of $\mathrm{NaCl}$ to the growth medium, such that salinity-treated plants were able to maintain a higher RGR than their non-salinity treated counterparts. In addition, they reduced toxicity, as indicated by lower

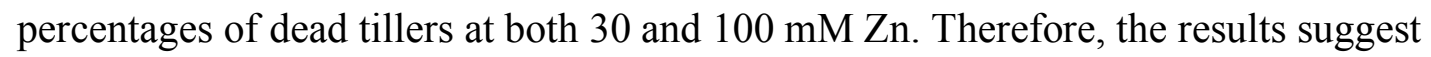
that salinity increases the tolerance of $J$. acutus to the toxic effects of high concentrations of $\mathrm{Zn}$. This interaction is consistent with results for species not recognized as hypertolerant to Zn: Redondo-Gómez et al. (2011) demonstrated that the addition $170 \mathrm{mM} \mathrm{NaCl}$ to a growth medium with $1 \mathrm{mM} \mathrm{Zn}$ diminished the damage caused by metal excess in Spartina densiflora, and Han et al. (2013) reported similar amelioration of the effects of $100 \mu \mathrm{M} \mathrm{Zn}$ by the addition of $50 \mathrm{mM} \mathrm{NaCl}$ to the growth medium with in Kosteletzkya virginica.

The mechanisms by which $\mathrm{NaCl}$ supplementation could enhance plant tolerance to elevated metal concentrations are not clear. Effects on metal uptake and translocation, and the resulting nutrient uptake balance have been described in certain estuarine species (Fitzgerald et al., 2003; Kadukova and Kalogerakis, 2007; Han et al., 2013). Redondo-Gómez et al. (2011) found that $\mathrm{NaCl}$ supplementation increased $\mathrm{Zn}$ accumulation in S. densiflora tissues compared with non-salinized plants, but this was accompanied by an overall improvement in nutrient uptake. Similar modifications in mineral content were recorded in Kosteletzkya virginica tissues in response to salinity and $\mathrm{Zn}$ (Han et al. 2013), but in that case $\mathrm{NaCl}$ addition acted through a modification of $\mathrm{Zn}$ distribution rather than a decrease in plant $\mathrm{Zn}$ uptake capacity. In contrast, we found that although tissues $\mathrm{Zn}$ concentrations in J. acutus increased markedly with the external concentration in accordance with previous studies, this increase was progressively lower as tissue $\mathrm{Na}$ concentration increased in response to $\mathrm{NaCl}$ supplementation. Furthermore, salinity hindered the uptake of most nutrients in the 
highest $\mathrm{Zn}$ concentration. These discrepancies may be ascribed to the severity of stress imposed, since a maximum concentration of $100 \mathrm{mM} \mathrm{Zn}$ was used in the present study whereas Redondo-Gómez et al. (2011) and Han et al. (2013) used only $1 \mathrm{mM}$ and 100 $\mu \mathrm{M}$, respectively. Reduced nutrient concentrations with the progressive accumulation of $\mathrm{Na}$ in roots and shoots have been found previously in other halophytes (RedondoGómez et al., 2007, 2010).

Notwithstanding the nutritional imbalance induced by $\mathrm{Na}$ accumulation, the lower concentrations of $\mathrm{Zn}$ in the tissues of plants grown in the presence of $\mathrm{NaCl}$ could help to explain their higher tolerance. Excess $\mathrm{Zn}$ accumulated in the tissues is likely to be toxic, affecting a variety of physiological and biochemical processes (KabataPendias and Pendias, 2001). However, despite such reductions in tissue $\mathrm{Zn}$ concentration in J. acutus, it must be acknowledged that concentrations were still greater than the toxicity threshold for plants generally (Kabata-Pendias and Pendias, 2001). Consequently, other mechanisms must be involved in the ameliorative effect of $\mathrm{NaCl}$ on $\mathrm{Zn}$ toxicity in $J$. acutus.

Metal hypertolerance has been associated with various ecophysiological adaptations to metalliferous environments (Evangelou et al., 2004; Mateos-Naranjo et al., 2014; Santos et al., 2014). In particular, Mateos-Naranjo et al. (2014) indicated that Zn hypertolerance in $J$. acutus was linked with its capacity to maintain carbon assimilation and the efficiency of PSII even at $\mathrm{Zn}$ concentration of $100 \mathrm{mM}$. In contrast we found a clear deleterious effect of $\mathrm{Zn}$ at this concentration on the photosynthetic apparatus in the present experiment; this discrepancy may be attributable to different experimental and measurement conditions. Although $\mathrm{A}_{\mathrm{N}}$ (along with $\mathrm{g}_{\mathrm{s}}$ ) decreased considerably with increasing $\mathrm{Zn}$ concentration, plants grown at $85 \mathrm{mM} \mathrm{NaCl}$ were able to maintain higher $A_{N}$ values than their non-saline counterparts. However, this positive 
effect cannot be attributed to alleviation of stomatal limitation, since $g_{s}$ values did not vary between salinity levels in either $\mathrm{Zn}$ treatment. Therefore, differences in $\mathrm{A}_{\mathrm{N}}$ value between $\mathrm{NaCl}$ levels et each specific $\mathrm{Zn}$ concentration treatment could be explained by non-stomatal limitations (Flexas and Medrano, 2002). In this regard, Perez-Romero et al. (2016) found that photosynthesis activity was more limited by mesophyll conductance $\left(\mathrm{g}_{\mathrm{m}}\right)$ than $\mathrm{g}_{\mathrm{s}}$ in Salicornia ramossisima in response to Cd. Moreover, $\mathrm{g}_{\mathrm{m}}$ has been widely implicated in photosynthetic responses patterns to salinity (Flexas et al., 2012). Hence, it is possible that $\mathrm{A}_{\mathrm{N}}$ differences between salinity levels in J. acutus plants at the same $\mathrm{Zn}$ concentration could be linked with $\mathrm{g}_{\mathrm{m}}$ variations; however this area requires further research. Another possibility relates to impairment of major carbon-assimilation enzyme activities, such as RuBisCO that may degrade the photosynthetic pathway under metal stress (Perfus-Barbeoch et al., 2002; Khan and Khan, 2014). A degree of metal tolerance has been demonstrated in the maintenance such enzyme functions (Ying et al., 2010; Pérez-Romero et al., 2016). Taking into account these issues, the higher $\mathrm{C}_{\mathrm{i}}$ in $J$. acutus plants grown without $\mathrm{NaCl}$ addition suggests that differences in carbon assimilation between salinity treatments could have been linked to limitation in RuBisCO carboxylation capacity (Mateos-Naranjo et al., 2008, 2014).

On the other hand, the greatest photosynthetic tolerance to $\mathrm{Zn}$-induced stress under saline conditions was associated with the highest integrity and functionality of the photochemical apparatus of $J$. acutus. It is known that $\mathrm{Zn}$ is concentrated in chloroplasts and interacts with the PSII donor, inhibiting the photosynthetic fixation of $\mathrm{CO}_{2}$ and the Hill reaction (Prasad and Strzalka, 1999). In addition, Monnet et al. (2001) indicated that the destruction of antenna pigments would affect the efficiency of PSII. Our results revealed that $\mathrm{F}_{\mathrm{v}} / \mathrm{F}_{\mathrm{m}}$ and $\Phi_{\mathrm{PSII}}$ values were affected by elevated $\mathrm{Zn}$ and this effect was 
more acute in plants grown in absence of $\mathrm{NaCl}$, suggesting that $\mathrm{NaCl}$ alleviates $\mathrm{Zn}$ induced, excess-light photoinhibition. Furthermore, under non-saline conditions and in presence of Zn, NPQ values were higher, which indicates that more of the absorbed energy would have been dissipated as heat and would not taken the photochemical pathway (Flexas et al., 2012). In line with our results, Padinha et al. (2000) and MateosNaranjo et al. (2008) also found that Zn stress affected the PSII photochemistry of the halophytes Spartina maritima and S. densiflora, respectively. Damage to photosynthetic components may lead to an increase of photoinhibition (Werner et al., 2002), a phenomenon that affects photosynthetic productivity and, consequently, plant growth (Melis, 1999). This fact could contribute to explaining our growth data, since chronic photoinhibition percentage increased in presence of $\mathrm{Zn}$ under non-saline conditions, whereas this increased photoinhibition was ameliorated under saline conditions, although less so in plants exposed to $100 \mathrm{mM}$ Zn. However, these plants showed a greater dynamic photoinhition percentage compared to other treatments, which would indicate an overcompensation effect of the excess of energy fixed, through thermal dissipation mechanisms, thereby protecting the leaf from light-induced damage (Maxwell and Johnson, 2000). In addition, the benefit of $\mathrm{NaCl}$ supplementation to photosynthetic-pigment concentration in the presence of $\mathrm{Zn}$ could contribute to explaining its positive effects on the photosynthetic apparatus efficiency of $J$. acutus.

Finally the greater tolerance to $\mathrm{Zn}$ in plants treated with $\mathrm{NaCl}$ was linked with a better water balance, an idea supported by the overall higher ${ }_{\mathrm{i}}$ WUE values. Thus, these plants would be able better to preserve the trade-off between $\mathrm{CO}_{2}$ acquisition for growth and water loss, as indicated the higher $A_{N}$ and the invariable $g_{s}$ values compared with their counterparts not treated with $\mathrm{NaCl}$. Han et al. (2013) also found a positive effect of $\mathrm{NaCl}$ supplementation on water relations, in Kosteletzkya virginica, under $\mathrm{Zn}$ excess. 
This beneficial effect could be linked with the key role of $\mathrm{Na}$ accumulation in plant osmotic adjustment (Shabala et al., 2009). Hence, it is possible that the higher $\mathrm{Na}$ concentration in tissues of $J$. acutus under saline conditions and the reduction in $g_{s}$ in the presence of $\mathrm{Zn}$ might help to alleviate any water stress ascribed to $\mathrm{Zn}$ toxicity.

\section{Conclusions}

We may conclude that the presence of $\mathrm{NaCl}$ in the growth medium, at concentrations representative of estuarine environments, considerably reduces the deleterious effects of elevated $\mathrm{Zn}$ concentrations on the growth and development of $J$. acutus. This beneficial effect was largely mediated by the reduction of Zn levels in $J$. acutus tissues, together with an overall protective effect on its photosynthetic apparatus, manifested as improved carbon harvesting, functionality of the photochemical apparatus (PSII) and photosynthetic pigment concentrations. Furthermore, amelioration by $\mathrm{NaCl}$ was linked with the maintenance of a more advantageous water balance. These ecophysiological characteristics would enhance the fitness and competitive ability of $J$. acutus in zinc-polluted estuaries and saltmarshes, providing a tolerant bio-tool for the management and restoration metal pollution in salinized lands. 
378 This work has been supported by Ministerio de Economía y Competitividad (MINECO 379 Project CGL2016-75550-R cofunded by FEDER). J.A Pérez-Romero thanks Ministerio 380 de Educación, Cultura y Deporte for its personal financial support (FPU014/03987). We 381 are grateful University of Seville Greenhouse General Services (CITIUS) for its 382 collaboration and Antonio León for his technical assistance. 


\section{References}

Chaney, R.L. 1993. Zinc phytotoxicity. En: Robson, A.D. (Ed.), Zinc in Soils and Plants. Kluwer Academic Press, New York, pp. 131-150

Christofilopoulos, S., Syranidou, E., Gkavrou, G., Manousaki, E., Kalogerakis, N. 2016. The role of halophyte Juncus acutus L. in the remediation of mixed contamination in a hydroponic greenhouse experiment. J. Chem. Technol. Biotechnol. 91 (6), $1665-1674$

Evangelou, M.W., Daghan, H., Schaeffer, A. 2004. The influence of humic acids on the phytoextraction of cadmium from soil. Chemosphere 57, 207-213.

Fernández-Carvajal, M.C. 1982. Revisión del género Juncus L. en la Península Ibérica. Anales del Jardín Botánico de Madrid 38, 417-467.

Fitzgerald, F.J., Caffrey, J.M., Nesaratnam, S.T., McLoughlin, P. 2003. Copper and lead concentrations in salt marsh plants on the Suir Estuary, Ireland. Environ. Pollut.123, 67-74.

Flexas, J., Medrano, H. 2002. Drought-inhibition of photosynthesis in C3 plants: stomatal and non-stomatal limitations revised. Ann. Bot-London 89, 183-189.

Flexas, J., Loreto, F., Medrano, H. 2012. Terrestrial photosynthesis in a changing environment. A molecular, physiological and ecological approach. Cambridge University Press. Cambridge, pp. 723.

Genty, B., Briantais, J.M., Baker, N.R. 1989. The relationship between the quantum yield of photosynthetic electron transport and quenching of chlorophyll fluorescence. Biochem. Biophys. Acta 990, 87-92. 
Han, R., Quinet, M., André, E., Teun van Elteren, J., Destrebecq, F., Vogel-Mikus, K., Cui, G., Debeljak, M., Lefevre, I., Lutts, S. 2013. Accumulation and distribution of $\mathrm{Zn}$ in the shoots and reproductive structures of the halophyte plant species Kosteletzkya virginica as a function of salinity. Planta 238, 441-457.

Hoagland, D., Arnon, D.I. 1938. The water culture method for growing plants without soil. Calif. Agric. Exp. St. Bull. 347, 1-39.

Kabata-Pendias, A., Pendias, H. 2001. Trace Elements in Soils and Plants. CRC Press, Boca Raton, Florida: CRC Press, 131-142.

Kadukova, J., Kalogerakis, N. 2007. Lead accumulation from non-saline and saline environments by Tamarix smyrnensis Bunge. Eur. J. Soil Biol.43, 216-223.

Khan, M.I.R., Khan, N.A. 2014. Ethylene reverses photosynthetic inhibition by nickel and zinc in mustard through changes in PS II activity, photosynthetic nitrogen use efficiency, and antioxidant metabolism. Protoplasma 251, 1007-1019.

Kholodova, V.P., Volkov, K., Kuznetsov, V. 2010. Plants under heavy metal stress in saline environments. In: Sherameti I, Varma A, eds. Soil Heavy Metals, Soil Biology, vol 19. Heidelberg, Germany: Springer-Verlag, pp. 163-183.

Lichtenthaler, H.K. 1987. Chlorophylls and carotenoids: pigments of photosynthetic biomembranes. Method. Enzymol.148, 350-382.

Liu, X., Shen, X., Lai, Y., Ji, K., Sun, H., Wang, Y., Hou, C., Zou, N., Wan, J., Yu, J. 2016. Toxicology proteomic responses of halophyte Suaeda salsa to lead and zinc. Ecotox. Environ. Safe 134, 163-171. 
Marques, B., Lillebo, A.L., Pereira, E., Duarte, A.C. 2011. Mercury cycling and sequestration in salt marshes sediments: An ecosystem service provided by Juncus maritimus and Scirpus maritimus. Environ. Pollut. 159, 1869-1876.

Mateos-Naranjo, E., Redondo-Gómez, S., Cambrollé, J., Luque, T., Figueroa, M.E. 2008. Growth and photosynthetic responses to zinc stress of an invasive cordgrass, Spartina densiflora. Plant Biology 10, 754-762.

Mateos-Naranjo, E., Andrades-Moreno, L., Redondo-Gómez, S., 2011. Comparison of germination, growth, photosynthetic responses and metal uptake between three populations of Spartina densiflora under different soil pollution conditions. Ecotox. Environ. Safe. 74, 2040-2049.

Mateos-Naranjo, E., Castellanos, E.M., Pérez-Martin, A. 2014. Zinc tolerance and acumulation in the halophytic species Juncus acutus. Environ. Exp. Bot.100, 114121.

Maxwell, K., Johnson, G.N. 2000. Chorophyll fluorescence a practical guide. J. Exp. Bot. 51, 659-668.

Medas, D., De Giudici, G., Pusceddu, C., Casu, M.A., Birarda, G., Vaccari, L., Gianoncelli, A., Meneghini, C. 2017. Impact of Zn excess on biomineralization processes in Juncus acutus grown in mine polluted sites. J. Hazard. Mat. In press. DOI: $10.1016 / j . j h a z m a t .2017 .08 .031$.

Melis, A., 1999. Photosystem-II damage and repair cycle in chloroplasts: what modulates the rate of photodamage in vivo?. Trends Plant. Sci. 4, 130-135. 
Monnet F., Vaillant N., Vernay P., Coudret A., Sallanon H., Hitmi A. 2001. Relationship between PSII activity, $\mathrm{CO}_{2}$ fixation, and $\mathrm{Zn}, \mathrm{Mn}$ and $\mathrm{Mg}$ contents of Lolium perenne under zinc stress. J. Plant Physiol. 158, 1137-1144.

Padinha, C., Santos, R., Brown, M.T. 2000. Evaluating environmental contamination in Ria Formosa (Portugal) using stress indexes of Spartina maritima. Mar. Environ. Res. 49, 67-78.

Paschke, M.W., Redente, E.F., Levy, D.B., 2000. Zinc toxicity thresholds for important reclamation grass species of the western United States. Environ. Toxicol. Chem. $19,2751-2756$

Pérez-Romero, J.A., Redondo-Gómez, S., Mateos-Naranjo, E. 2016. Growth and photosynthetic limitation analysis of the Cd-accumulator Salicornia ramosissima under excessive cadmium concentrations and optimum salinity conditions. Plant Physiol. Bioch. 109, 103-113.

Perfus-Barbeoch, L., Leonhardt, N., Vavasseur A., Forestier, C., 2002. Heavy metal toxicity: cadmium permeates through calcium channels and disturbs the plant water status. Plant J. 32, 539-548.

Prasad, M.N.V., Strzalka, K. 1999. Impact of heavy metals on photosynthesis. In: Prasad MNV, Hagemeyer J, eds. Heavy Metals Stress in Plants: from Molecules to Ecosystems. Berlin, Germany: Springer, 117-138.

Redondo-Gómez, S., Mateos-Naranjo, E., Davy, A.J., Fernández-Muñoz, F., Castellanos, E., Luque, T., Figueroa, M.E. 2007. Growth and photosynthetic responses to salinity of the salt-marsh shrub Atriplex portulacoides. Annal. Bot. $100,555-563$. 
471 Redondo-Gómez, S., Mateos-Naranjo, E., Figueroa, M.E., Davy, A.J., 2010. Salt

472 stimulation of growth and photosynthesis in an extreme halophyte, Arthrocnemum macrostachyum. Plant Biology 12, 79-87.

Redondo-Gómez, S., Andrades-Moreno, L., Mateos-Naranjo, E., Parra, R., ValeraBurgos, J., Aroca, R. 2011. Synergic effect of salinity and zinc stress on growth and photosynthetic responses of the cordgrass Spartina densiflora. J. Exp. Bot. 62, $5521-5530$.

Santos, D., Duarte, B., Caçador, I., 2014. Unveiling Zn hyperaccumulation in Juncus acutus: implications on the electronic energy fluxes and on oxidative stress with emphasis on non-functional Zn-chlorophylls. J. Photochem. Photobiol. B 140, 228-239

Schreiber, U., Schliw, U., Bilger, W. 1986. Continuous recording of photochemical and non-photochemical chlorophyll fluorescence quenching with a new type of modulation fluorimeter. Photosynth Res. 10, 51-62.

Shabala, L., McMeekin, T. Shabala S. 2009. Osmotic adjustment and requirement for sodium in marine protist thraustochytrid. Environ. Microbiol. 11, 1835-1843.

Sparks, E.L., Cebrian, J., Bilber, P.D., Sheehan, K.L., Tobias, C.R. 2013. Costeffectiveness of two small-scale salt marsh restoration designs. Ecol. Eng. 53, 250-256.

Vaillant, N., Monnet, F., Hitmi, A., Sallanon, H., Coudret, A. 2005. Comparative study of responses in four Datura species to zinc stress. Chemosphere 59, 1005-1013.

Van Assche, F.V. Clijsters, H. 1986. Inhibition of photosynthesis by treatment of Phaseolus vulgaris with toxic concentration of zinc: effects on electron transport 
and photophosphorylation. Physiol. Plantarum 66, 717-721.

495 Werner, C., Correia, O., Beyschlag, W. 2002. Characteristic patterns of chronic and dynamic photoinhibition of different functional groups in a Mediterranean ecosystem. Funct. Plant Biol. 29, 999-1011.

498 Ying R.R, Qiu., R.L., Tang Y.T., Hu P.J., Qiu H., Chen H.R., Shi T.H., Morel J.L. 499 2010. Cadmium tolerance of carbon assimilation enzymes and chloroplast in $500 \quad$ Zn/Cd hyperaccumulator Picris divaricata. J. Plant Physiol. 167 81-87. 
503 Table 1. Generalized linear model (GLM) results for the growth, physiological and 504 tissues ions concentration of $J$. acutus plants in response to $\mathrm{Zn}$ and $\mathrm{NaCl}$ concentration 505 (as categorical variables) and its interaction. * Significance level $95 \%$ and ** 506 Significance level 99\%. Md (midday), Pd (predawn), T (tiller and R (root).

507

508

509

510

511

512

513

514

515

516

517

518

519

520

521

522

\begin{tabular}{|c|c|c|c|}
\hline Parameter & $\mathrm{Na}$ & $Z n$ & $N a \times Z n$ \\
\hline RGR & 0.03* & $0.00 * *$ & 0.06 \\
\hline Dead Tillers & 0.07 & $0.00 * *$ & 0.19 \\
\hline $\mathrm{A}_{\mathrm{N}}$ & $0.02 *$ & $0.00 * *$ & 0.01* \\
\hline $\mathrm{g}_{\mathrm{s}}$ & 0.30 & $0.00 * *$ & 0.06 \\
\hline $\mathrm{C}_{\mathrm{i}}$ & 0.04* & 0.05 & 0.22 \\
\hline iWUE & $0.02 *$ & $0.00 * *$ & 0.03* \\
\hline $\mathrm{F}_{\mathrm{v}} / \mathrm{F}_{\mathrm{m}, \mathrm{Md}}$ & 0.00* & $0.00 * *$ & $0.02 *$ \\
\hline $\mathrm{F}_{\mathrm{v}} / \mathrm{F}_{\mathrm{m}, \mathrm{Pd}}$ & $0.00 * *$ & $0.00 * *$ & $0.02 *$ \\
\hline$\Phi_{\text {PSII, Md }}$ & 0.09 & $0.00 * *$ & $0.02 *$ \\
\hline$\Phi_{\text {PSII, Pd }}$ & $0.01 * *$ & $0.00 * *$ & 0.06 \\
\hline NPQ,,${ }^{2}$ & $0.01 * *$ & $0.00 * *$ & 0.10 \\
\hline NPQ, Pd & 0.63 & 0.51 & 0.62 \\
\hline Chl $a$ & $0.00 * *$ & 0.88 & $0.00 * *$ \\
\hline Chl $b$ & 0.06 & 0.57 & $0.04 *$ \\
\hline $\mathrm{C} x+c$ & $0.02 *$ & 0.22 & 0.04* \\
\hline$[\mathrm{Zn}]_{\mathrm{T}}$ & $0.00 * *$ & $0.00 * *$ & $0.00 * *$ \\
\hline$[\mathrm{Zn}]_{\mathrm{R}}$ & $0.00 * *$ & $0.00 * *$ & $0.00 * *$ \\
\hline$[\mathrm{Na}]_{\mathrm{T}}$ & $0.00 * *$ & $0.00 * *$ & $0.00 * *$ \\
\hline$[\mathrm{Na}]_{\mathrm{R}}$ & $0.00 * *$ & $0.00 * *$ & $0.00 * *$ \\
\hline$[\mathrm{K}]_{\mathrm{T}}$ & 0.95 & 0.58 & 0.47 \\
\hline$[\mathrm{K}]_{\mathrm{R}}$ & $0.00 * *$ & $0.00 * *$ & $0.00 * *$ \\
\hline$[\mathrm{Mg}]_{\mathrm{T}}$ & $0.00 * *$ & $0.00 * *$ & $0.00 * *$ \\
\hline$[\mathrm{Mg}]_{\mathrm{R}}$ & $0.00 * *$ & $0.00 * *$ & $0.00 * *$ \\
\hline$[\mathrm{Ca}]_{\mathrm{T}}$ & $0.00 * *$ & $0.00 * *$ & $0.00 * *$ \\
\hline$[\mathrm{Ca}]_{\mathrm{R}}$ & $0.00 * *$ & $0.00 * *$ & $0.00 * *$ \\
\hline$[\mathrm{P}]_{\mathrm{T}}$ & $0.02 *$ & $0.00 * *$ & 0.04* \\
\hline$[\mathrm{P}]_{\mathrm{R}}$ & 0.00** & $0.00 * *$ & $0.01 * *$ \\
\hline$[\mathrm{Mn}]_{\mathrm{T}}$ & 0.78 & $0.00 * *$ & 0.88 \\
\hline$[\mathrm{Mn}]_{\mathrm{R}}$ & $0.00 * *$ & $0.00 * *$ & $0.00 * *$ \\
\hline
\end{tabular}

523

524 
Table 2. Ion concentration in tiller and roots of Juncus acutus treated with a range of $\mathrm{Zn}$ concentration in combination with $0 \mathrm{mM}$ and $85 \mathrm{mM}$ $\mathrm{NaCl}$, after 40 days. Values represent mean $\pm \mathrm{SE}, \mathrm{n}=5$.

\begin{tabular}{|c|c|c|c|c|c|c|c|c|}
\hline \multicolumn{9}{|c|}{ Treatments } \\
\hline \multirow[b]{2}{*}{ Zn (mM) } & \multirow[b]{2}{*}{$\mathrm{NaCl}(\mathrm{mM})$} & \multicolumn{7}{|c|}{ Tiller concentration } \\
\hline & & $\mathrm{Zn}\left(\mathrm{mg} \mathrm{Kg}^{-1}\right)$ & $\mathrm{Na}\left(\mathrm{mg} \mathrm{g}^{-1}\right)$ & $\mathrm{K}\left(\mathrm{mg} \mathrm{g}^{-1}\right)$ & $\operatorname{Mg}\left(\mathrm{mg} \mathrm{g}^{-1}\right)$ & $\mathrm{Ca}\left(\mathrm{mg} \mathrm{g}^{-1}\right)$ & $P\left(\mathrm{mg} \mathrm{g}^{-1}\right)$ & $\operatorname{Mn}\left(m g K g^{-1}\right)$ \\
\hline $\mathbf{0}$ & $\mathbf{0}$ & $32.3 \pm 0.5^{\mathrm{a}}$ & $0.97 \pm 0.1^{\mathrm{a}}$ & $29.9 \pm 0.1^{\mathrm{a}}$ & $3.54 \pm 0.3^{\mathrm{a}}$ & $5.89 \pm 0.1^{\mathrm{a}}$ & $2.95 \pm 0.2^{\mathrm{a}}$ & $35.5 \pm 0.6^{\mathrm{a}}$ \\
\hline 30 & $\mathbf{0}$ & $304.6 \pm 1.4^{b}$ & $1.84 \pm 0.2^{b}$ & $29.4 \pm 0.3^{\mathrm{a}}$ & $3.19 \pm 0.2^{\mathrm{a}}$ & $4.97 \pm 0.2^{b}$ & $2.39 \pm 0.1^{b}$ & $27.3 \pm 0.3^{b}$ \\
\hline 100 & $\mathbf{0}$ & $611.7 \pm 0.8^{c}$ & $3.65 \pm 0.2^{\mathrm{c}}$ & $30.2 \pm 0.1^{\mathrm{a}}$ & $3.04 \pm 0.1^{\mathrm{a}}$ & $4.09 \pm 0.2^{\mathrm{c}}$ & $2.50 \pm 0.2^{\mathrm{b}}$ & $23.9 \pm 0.4^{\mathrm{c}}$ \\
\hline $\mathbf{0}$ & 85 & $36.9 \pm 0.6^{\mathrm{a}}$ & $7.75 \pm 0.5^{\mathrm{d}}$ & $28.9 \pm 0.5^{\mathrm{a}}$ & $3.31 \pm 0.3^{\mathrm{a}}$ & $4.20 \pm 0.2^{\mathrm{c}}$ & $2.89 \pm 0.5^{\mathrm{a}}$ & $32.7 \pm 0.2^{\mathrm{a}}$ \\
\hline 30 & 85 & $248.5 \pm 0.5^{d}$ & $6.96 \pm 0.1^{\mathrm{e}}$ & $29.7 \pm 0.2^{\mathrm{a}}$ & $3.06 \pm 0.2^{\mathrm{a}}$ & $3.85 \pm 0.4^{\mathrm{c}}$ & $2.82 \pm 0.2^{\mathrm{a}}$ & $27.3 \pm 0.4^{b}$ \\
\hline \multirow[t]{2}{*}{100} & 85 & $412.3 \pm 1.1^{\mathrm{e}}$ & $8.41 \pm 0.3^{\mathrm{d}}$ & $30.9 \pm 0.3^{\mathrm{a}}$ & $2.83 \pm 0.1^{\mathrm{b}}$ & $3.71 \pm 0.3^{\mathrm{c}}$ & $2.52 \pm 0.3^{b}$ & $22.9 \pm 0.1^{\mathrm{c}}$ \\
\hline & & \multicolumn{7}{|c|}{ Root concentration } \\
\hline $\mathbf{0}$ & $\mathbf{0}$ & $87.3 \pm 0.7^{\mathrm{a}}$ & $1.48 \pm 0.1^{\mathrm{a}}$ & $28.9 \pm 0.2^{\mathrm{a}}$ & $5.48 \pm 0.2^{\mathrm{a}}$ & $15.84 \pm 0.5^{\mathrm{a}}$ & $3.36 \pm 0.5^{\mathrm{ab}}$ & $39.3 \pm 0.2^{\mathrm{a}}$ \\
\hline 30 & $\mathbf{0}$ & $2122.6 \pm 1.3^{\mathrm{b}}$ & $2.92 \pm 0.2^{b}$ & $24.5 \pm 0.3^{b}$ & $4.60 \pm 0.2^{\mathrm{a}}$ & $17.36 \pm 0.2^{\mathrm{a}}$ & $4.25 \pm 0.5^{\mathrm{a}}$ & $39.9 \pm 0.4^{\mathrm{a}}$ \\
\hline 100 & $\mathbf{0}$ & $2479.0 \pm 0.3^{\mathrm{c}}$ & $5.78 \pm 0.4^{c}$ & $16.8 \pm 0.4^{\mathrm{c}}$ & $4.07 \pm 0.1^{b}$ & $8.54 \pm 0.2^{\mathrm{b}}$ & $2.39 \pm 0.2^{b}$ & $33.5 \pm 0.1^{b}$ \\
\hline 0 & 85 & $58.4 \pm 1.2^{\mathrm{d}}$ & $21.17 \pm 0.2^{\mathrm{d}}$ & $20.2 \pm 0.4^{b}$ & $4.87 \pm 0.2^{\mathrm{a}}$ & $13.27 \pm 0.6^{\mathrm{a}}$ & $2.63 \pm 0.1^{\mathrm{b}}$ & $33.5 \pm 0.1^{\mathrm{b}}$ \\
\hline 30 & 85 & $1455.4 \pm 2.2^{\mathrm{e}}$ & $16.14 \pm 0.3^{\mathrm{e}}$ & $20.5 \pm 0.2^{b}$ & $3.62 \pm 0.1^{\mathrm{b}}$ & $8.67 \pm 0.2^{\mathrm{b}}$ & $2.71 \pm 0.1^{\mathrm{b}}$ & $27.5 \pm 0.2^{\mathrm{c}}$ \\
\hline 100 & 85 & $1969.2 \pm 1.1^{\mathrm{f}}$ & $13.95 \pm 0.4^{\mathrm{f}}$ & $17.3 \pm 0.3^{c}$ & $3.41 \pm 0.2^{\mathrm{c}}$ & $4.89 \pm 0.1^{\mathrm{c}}$ & $2.67 \pm 0.1^{\mathrm{b}}$ & $26.4 \pm 0.2^{\mathrm{c}}$ \\
\hline
\end{tabular}

Different letters indicate means that are significantly different from each other 


\section{Figure legends}

Fig. 1. Relative growth rate, RGR (A) and percentage of dead tillers (B) in Juncus acutus plants in response to a treatment with a range of $\mathrm{Zn}$ concentration with $(\mathbf{O})$ and without (O) $\mathrm{NaCl}$ addition, after 40 days. Values represent mean $\pm \mathrm{SE}, \mathrm{n}=10$. Different letters indicate means that are significantly different from each other (LSD test, $\mathrm{P}<$ $0.05)$.

Fig. 2. Net photosynthetic rate, $A_{N}(A)$, stomatal conductance, $g_{s}(B)$, intercellular $\mathrm{CO}_{2}$ concentration, $C_{i}(C)$, and intrinsic water use efficiency, ${ }_{i} W U E(D)$ in randomly selected, fully developed photosynthetic tiller of Juncus acutus treated with a range of $\mathrm{Zn}$ concentration with $(\mathbf{O})$ and without $(\mathrm{O}) \mathrm{NaCl}$ addition, after 40 days. Values represent mean $\pm \mathrm{SE}, \mathrm{n}=10$. Different letters indicate means that are significantly different from each other (LSD test, $\mathrm{P}<0.05$ ).

Fig. 3. Maximum quantum efficiency of PSII photochemistry, $F_{v} / F_{m}(A, B)$, quantum efficiency of PSII, ФPSII (B,C), and non-photochemical quenching, NPQ (D,E), at midday and predawn in randomly selected, fully developed photosynthetic tiller of Juncus acutus treated with a range of $\mathrm{Zn}$ concentration with $(\mathbf{O})$ and without $(\mathrm{O}) \mathrm{NaCl}$ addition, after 40 days. Values represent mean $\pm \mathrm{SE}, \mathrm{n}=10$. Different letters indicate means that are significantly different from each other (LSD test, $\mathrm{P}<0.05$ ).

Fig. 4. Total chronic and $(\bullet)$ and dynamic $(\circ)$ photoinhibition percentage in randomly selected, fully developed photosynthetic tiller of Juncus acutus treated with a range of $\mathrm{Zn}$ concentration at $0 \mathrm{mM}$ (A) and $85 \mathrm{mM}$ (B) $\mathrm{NaCl}$ concentration, after 40 days. Values represent absolute percentage per each specific treatment. 
Fig. 5. Chlorophyll a, Chl $a$ (A), chlorophyll b, Chl $b$ (B) and carotenoids, $\mathrm{C} x+c$ (C) concentrations in randomly selected, fully developed photosynthetic tiller of Juncus acutus treated with a range of $\mathrm{Zn}$ concentration with $(0)$ and without $(\mathrm{O}) \mathrm{NaCl}$ addition, after 40 days. Values represent mean $\pm \mathrm{SE}, \mathrm{n}=5$. Different letters indicate means that are significantly different from each other (LSD test, $\mathrm{P}<0.05$ ). 
Fig. 1

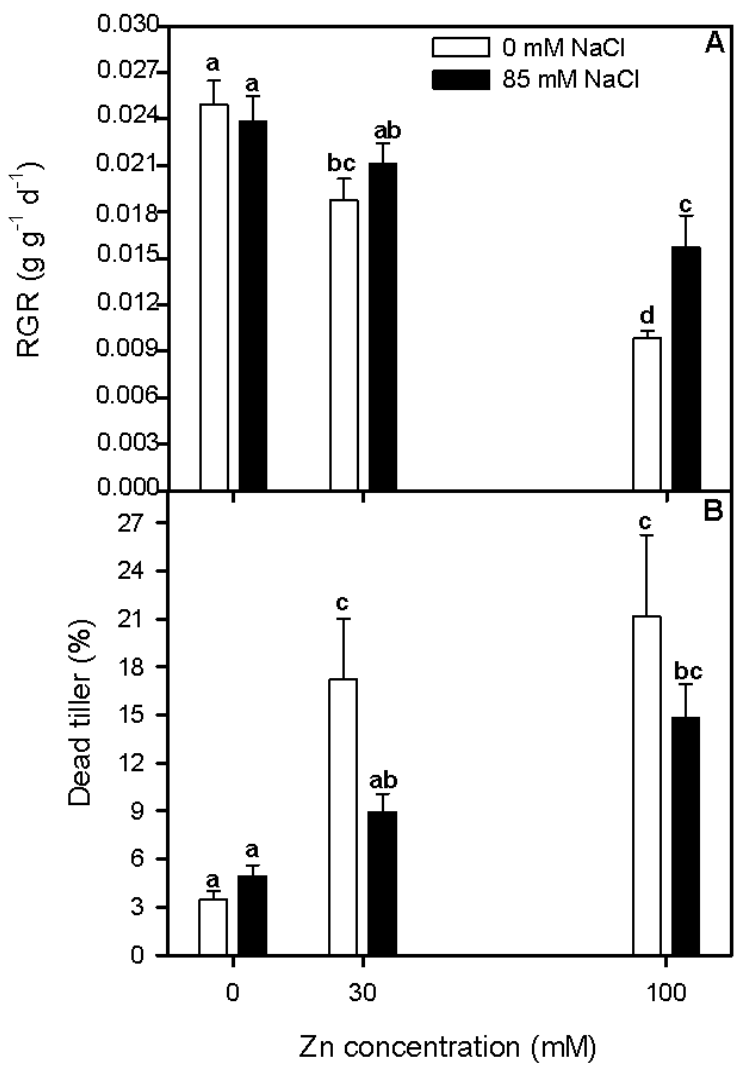


Fig. 2

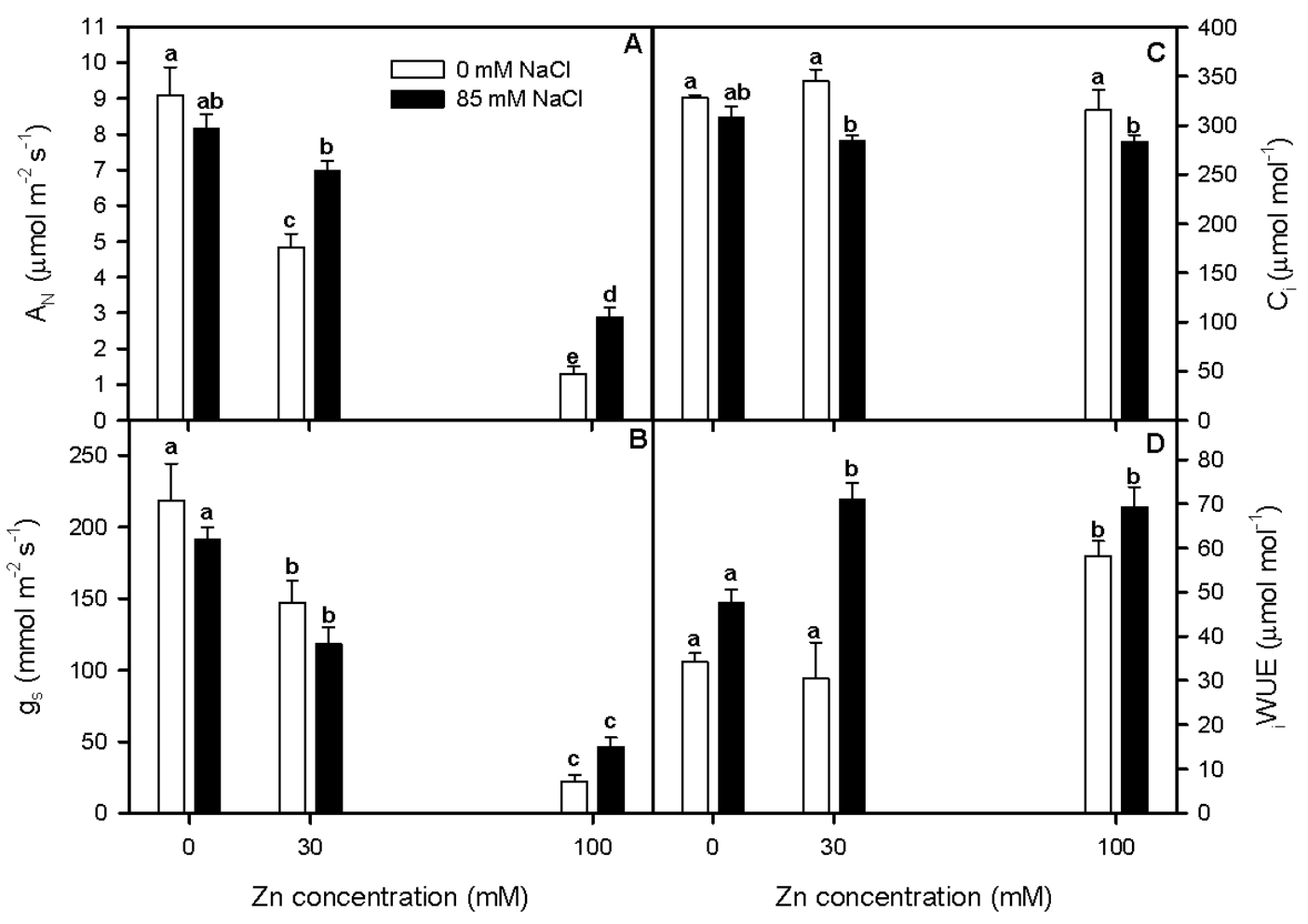


Fig. 3

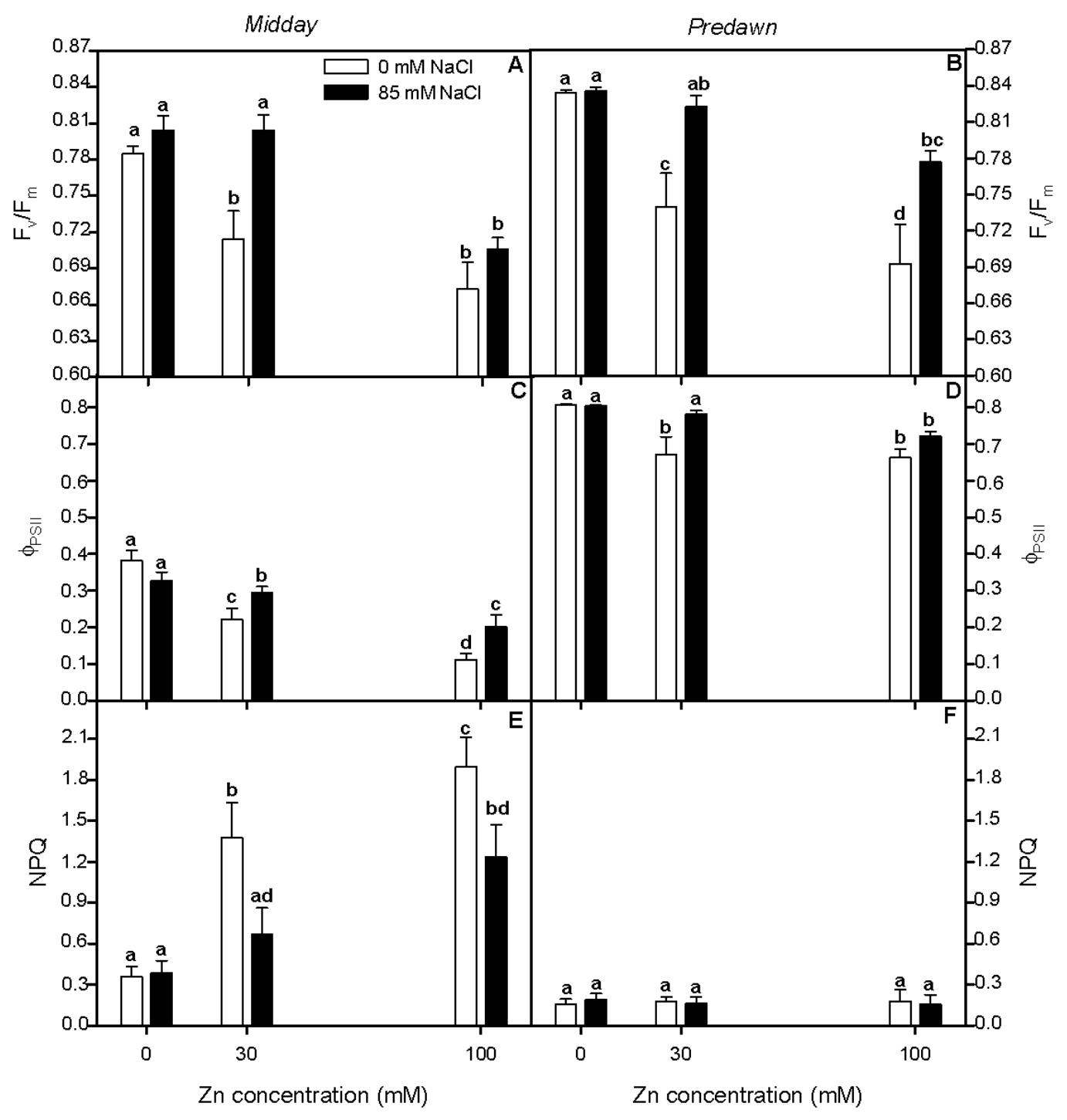


Fig. 4

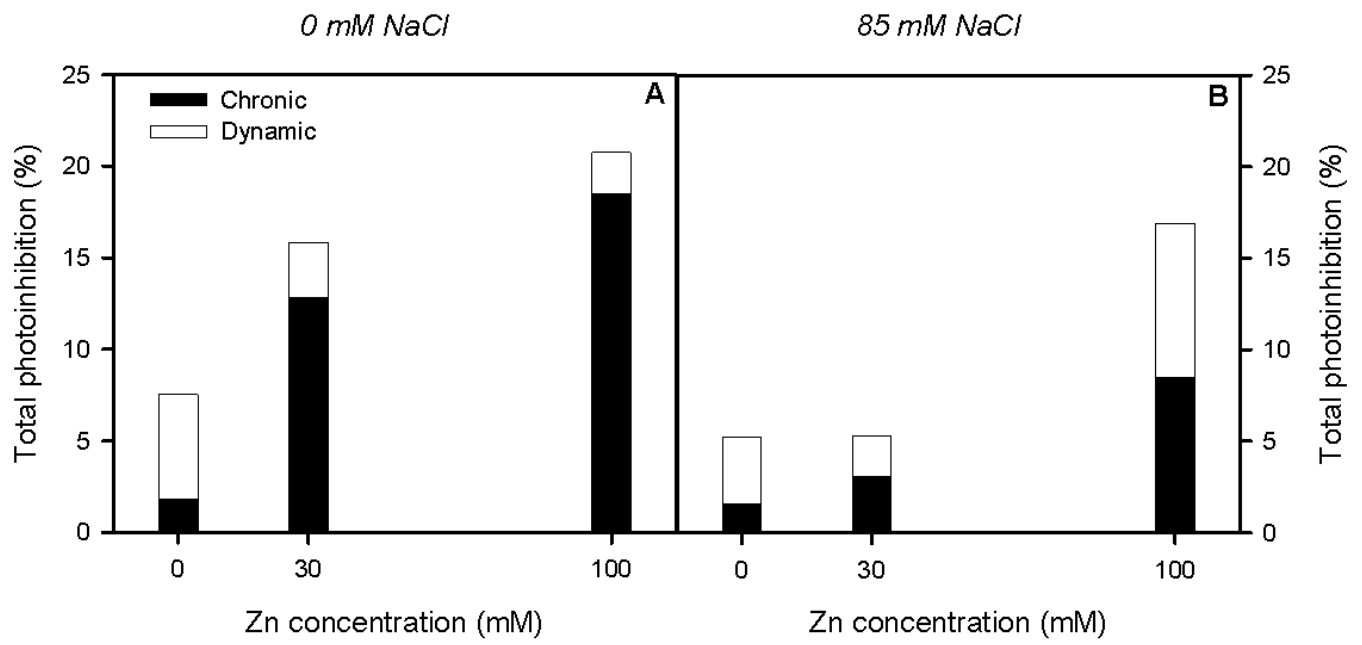


Fig. 5

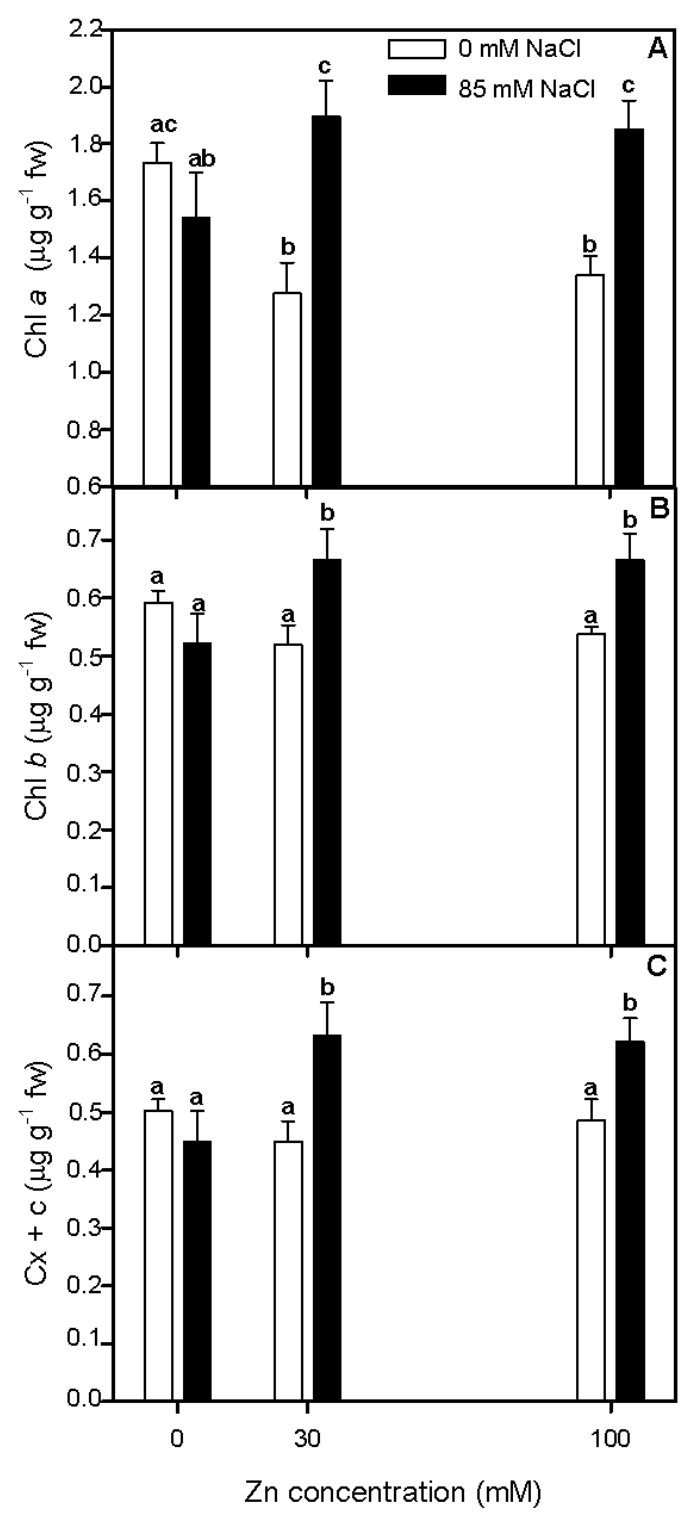

